Available online at http://journal.stkip-andi-matappa.ac.id/index.php/histogram/index

Histogram: Jurnal Pendidikan Matematika 4(2)., 2020, 409 - 422

\title{
PSEUDO ABSTRAKSI REFLEKTIF DALAM MENYELESAIKAN MASALAH BARISAN BILANGAN
}

\author{
Surya Sari Faradiba ${ }^{1 *}$, Anies Fuady ${ }^{2}$, Desy Nofita Sari ${ }^{3)}$ \\ ${ }^{1,2,3}$ Universitas Islam Malang \\ * Corresponding Author . Email : suryasarifaradiba@unisma.ac.id \\ Received: 21 Juli 2020; Revised: 15 September 2020 ; Accepted: 30 September 2020
}

\begin{abstract}
ABSTRAK
Penelitian ini adalah penelitian deskriptif. Tujuan penelitian adalah untuk mendeskripsikan proses abstraksi reflektif yang dialami oleh siswa. Subjek penelitian adalah seorang siswa kelas VIII. Teknik sampling yang digunakan adalah purposive sampling. Subjek dipilih karena mempertimbangkan kemampuan komunikasinya yang cukup baik dibandingan teman-teman seusianya sehingga memudahkan peneliti dalam menggali data. Selain itu, subjek terpilih merupakan siswa dengan prestasi akademik yang sangat memuaskan dibandingkan teman-teman sekelasnya. Penelitian ini mengulas dan menjelaskan abstraksi reflektif yang dilakukan subjek dalam menyelesaikan masalah barisan bilangan. Hal yang menjadi fokus penelitian adalah proses abstraksi reflektif yang meliputi interiorisasi, koordinasi, pembalikan, enkapsulasi, dan generalisasi. Hasil penelitian menunjukkan tahapan abstraksi reflektif tidak menjamin sampai pada solusi yang benar. Dalam penelitian ini subjek melakukan semua tahap abstraksi reflektif mulai dari interiorisasi, koordinasi, pembalikan, enkapsulasi, dan generalisasi, namun solusi akhirnya salah. Fenomena ini dikatakan sebagai pseudo abstraksi reflektif atau abstraksi reflektif sетu.
\end{abstract}

Kata Kunci: abstraksi reflektif, interiorisasi, koordinasi, pembalikan, enkapsulasi.

\section{ABSTRACT}

This research is a descriptive study. The research objective was to describe the reflective abstraction process experienced by students. The research subject was a class VIII student. The sampling technique used was purposive sampling. The subjects were chosen because they considered their communication skills which were quite good compared to their peers, making it easier for researchers to explore data. In addition, the selected subjects were students with very satisfying academic achievements compared to their classmates. This study examines and explains the reflective abstraction that the subject does in solving the number sequence problem. The focus of research is the process of reflective abstraction which includes interiorization, coordination, reversal, encapsulation, and generalization. The results showed that the reflective abstraction stage did not guarantee arriving at the correct solution. In this study the subject performs all stages of reflective abstraction starting from interiorization, coordination, reversal, encapsulation, and generalization, but the final solution is wrong. This phenomenon is said to be pseudo-reflective abstraction or pseudo-reflective abstraction.

Keywords: reflective abstraction, interiorization, coordination, reversal, encapsulation.

How to Cite: Faradiba, S, S., Fuady, A., \& Sari, D, N. (2020). Pseudo Abstraksi Reflektif Dalam Menyelesaikan Masalah Barisan Bilangan. Histogram: Jurnal Pendidikan Matematika, 4(2), 409 - 422, doi: http://dx.doi.org/10.31100/histogram.v4i2.685

Permalink/DOI: http://dx.doi.org/10.31100/histogram.v4i2.685

\section{PENDAHULUAN}

Simon, dkk (2004: 36) mengemukakan bahwa belajar matematika adalah proses transformasi dari pengetahuan dan tindakan seseorang. Sebagai proses transformasi, telah

Copyright $($ 2020, THE AUTHOR (S). This article distributed under the CC-BY-SA-license. 


\section{Histogram: Jurnal Pendidikan Matematika, 4 (2), 2020 - 410 \\ Surya Sari Faradiba' ${ }^{1 *}$, Anies Fuady ${ }^{2)}$, Desy Nofita Sari3)}

banyak penelitian menunjukkan bahwa terdapat kesulitan dalam matematika tingkat lanjut, terutama untuk siswa tahun pertama. Sejalan dengan hal tersebut, Nardi (2017: 11) menunjukkan ada ketegangan kognisi dalam proses transisi dari matematika sekolah menjadi matematika tingkat lanjut. Penelitian terhadap 79 responden dari 21 negara juga menunjukkan bahwa 91,1\% responden mengatakan mereka memiliki masalah dalam hal transisi. Lebih lanjut, dalam penelitian ini ditemukan bahwa dua pertiga responden mengakui adanya masalah yang timbul dari perbedaan karakteristik matematika sekolah dan matematika tingkat lanjut. Matematika sekolah cenderung mempelajari matematika secara prosedural. Sementara itu, matematika di jenjang yang lebih tinggi menekankan pada pemahaman secara konseptual. Penelitian ini juga menunjukkan lima konsep matematika yang memiliki pemahaman terendah, yaitu materi tentang pembuktian, limit, matriks aljabar, jumlah Riemann, serta barisan dan deret (Thomas, dkk: 2015: 267).

Pada awal matematika tingkat lanjut menurut Nardi (2017: 11), kemampuan abstraksi matematika merupakan hal yang mendesak. Pernyataan ini sejalan dengan Beth \& Piaget (dalam Nisa, 2020: 1) yang menyatakan bahwa abstraksi reflektif sangat penting untuk pengembangan konsep matematika lanjutan karena konstruk matematika diproses melalui abstraksi reflektif. Untuk mengatasi transisi ini Nardi (2017: 17), menyarankan agar belajar matematika pada tingkat lanjut harus mencakup lima karakteristik, yaitu: collaborative, mathematically focused, specific, non-prescriptive, dan non-deficit contexts. Sejalan dengan pendapat tersebut, Panasuk (2011) menyatakan bahwa dalam pembelajaran matematika kemampuan siswa berabstraksi adalah ketrampilan yang sangat penting. Pernyataan ini sejalan dengan Beth \& Piaget (dalam Nisa, 2020: 1) yang menyatakan bahwa abstraksi reflektif itu sangat berperan untuk pengembangan konsep matematika lanjutan karena konstruk matematika diproses melalui abstraksi reflektif.

Tujuan dari penelitian ini adalah untuk mengetahui bagaimana proses konstruksi abstraksi reflektif sebagai mekanisme mental dalam konsep Barisan Bilangan. Jika penelitian sebelumnya sebagian besar dilakukan pada materi matematika lanjutan, penelitian ini meneliti subjek awal matematika tingkat lanjut, seperti yang dilakukan oleh Maharaj (2014: 54) yang menggunakan materi Integral. Menjelajahi proses konseptualisasi konsep awal pembelajaran siswa itu penting karena akan terlihat kendala siswa dalam proses transisi berpikir dari matematika sekolah ke matematika lanjutan, seperti Analisis Riil, Topologi, dan Teori Bilangan. 


\section{Histogram: Jurnal Pendidikan Matematika, 4 (2), 2020 - 411 \\ Surya Sari Faradiba ${ }^{1)^{*}}$, Anies Fuady²), Desy Nofita Sari3)}

\section{METODE PENELITIAN}

Penelitian ini adalah penelitian deskriptif. Deskripsi muncul setelah eksplorasi kreatif, dan berfungsi untuk mengatur temuan agar sesuai dengan penjelasan, dan kemudian menguji atau memvalidasi penjelasan tersebut (Krathwohl, 1993). Banyak studi penelitian menghimbau untuk mendeskripsikan fenomena alam atau buatan manusia seperti bentuk, struktur, aktivitas, perubahan dari waktu ke waktu, hubungannya dengan fenomena lain, dan sebagainya. Deskripsi seringkali dapat memperjelas suatu fenomena yang mungkin tidak kita sadari. Lebih lanjut, penelitian deskriptif sesuai digunakan dalam penelitian di bidang Pendidikan yang identik menggunakan teknik observasi, survei, dan wawancara untuk mengumpulkan data.

Subjek penelitian adalah seorang siswa SMP kelas VIII di Kota Malang. Teknik sampling yang digunakan adalah purposive sampling supaya peneliti dapat fokus mendalami proses abstraksi reflektif yang sedang dilakukan oleh subjek. Subjek dipilih karena mempertimbangkan kemampuan komunikasinya yang cukup baik dibandingan teman-teman seusianya sehingga memudahkan peneliti dalam menggali data. Hal ini bisa dilihat dari keluwesan subjek saat menjelaskan hasil jawaban dari soal yang telah diberikan saat studi pendahuluan. Selain itu, berdasarkan informasi dari guru kelas, subjek terpilih merupakan siswa dengan prestasi akademik yang sangat memuaskan dibandingkan temanteman sekelasnya. Penelitian ini mengulas dan menjelaskan abstraksi reflektif yang dilakukan subjek dalam menyelesaikan masalah barisan bilangan. Hal yang menjadi fokus penelitian adalah proses abstraksi reflektif yang meliputi interiorisasi (Interiorization), koordinasi (Coordination), pembalikan (Reversal), enkapsulasi (Encapsulation), dan generalisasi (Generalization). Adapun deskripsi untuk masing-masing komponen dapat dilihat dalam Tabel 1.

Tabel 1. Deskripsi Komponen Abstraksi Reflektif

\begin{tabular}{ccll}
\hline No. & $\begin{array}{c}\text { Komponen- } \\
\text { komponen } \\
\text { Abstraksi } \\
\text { Reflektif }\end{array}$ & \multicolumn{1}{c}{ Deskripsi } & Indikator Komponen \\
& Interiorisasi & $\begin{array}{l}\text { Tindakan mengonstruksi proses- } \\
\text { proses internal dalam memahami } \\
\text { fenomena atau kejadian yang } \\
\end{array}$ & $\begin{array}{l}\text { Diawali dengan kata } \\
\text { kerja "membaca dan } \\
\text { mengamati". }\end{array}$ \\
& & kialami. Aktivitas berpikir dalam \\
& & \\
& & \\
& &
\end{tabular}


Histogram: Jurnal Pendidikan Matematika, 4 (2), 2020 - 412

Surya Sari Faradiba' ${ }^{*}$, Anies Fuady²), Desy Nofita Sari ${ }^{3}$ )

\begin{tabular}{|c|c|c|c|}
\hline No. & $\begin{array}{c}\text { Komponen- } \\
\text { komponen } \\
\text { Abstraksi } \\
\text { Reflektif }\end{array}$ & Deskripsi & Indikator Komponen \\
\hline & & $\begin{array}{l}\text { menggali informasi-informasi } \\
\text { yang diperlukan. }\end{array}$ & \\
\hline 2 & Koordinasi & $\begin{array}{l}\text { Tindakan mengonstruksi proses } \\
\text { baru dari dua atau lebih proses lain } \\
\text { yang telah dialami atau } \\
\text { mengkoordinasi hasil dan } \\
\text { interiorisasi }\end{array}$ & $\begin{array}{l}\text { Diawali dengan kata } \\
\text { kerja } \\
\text { "mengkoordinasikan, } \\
\text { menghitung". }\end{array}$ \\
\hline 3 & Enkapsulasi & $\begin{array}{l}\text { Tindakan mengonstruksi objek } \\
\text { mental dari proses mental atau } \\
\text { proses secara kontekstual yang } \\
\text { harus dilibatkan. Objek mental } \\
\text { bersifat statis dan proses mental } \\
\text { bersifat dinamis. }\end{array}$ & $\begin{array}{l}\text { Diawali dengan kata } \\
\text { kerja "menetapkan". }\end{array}$ \\
\hline 4 & Generalisasi & $\begin{array}{l}\text { Menerapkan skema menuju bentuk } \\
\text { yang lebih luas dari suatu kejadian. }\end{array}$ & $\begin{array}{l}\text { Diawali dengan kata } \\
\text { kerja "menggunakan". }\end{array}$ \\
\hline
\end{tabular}

(Sumber: Fuady, 2017: 43)

Data dikumpulkan dengan dokumentasi, observasi, tes dan wawancara terstruktur. Analisis data yang digunakan oleh peneliti dalam penelitian ini adalah model interaktif dari Miles dan Huberman (1992). Terdapat tiga komponen utama dalam analisis data model interaktif, yaitu: (1) reduksi data, (2) penyajian data, dan (3) penarikan kesimpulan/verifikasi. Tahap reduksi data merupakan tahapan proses pemilihan, penyederhanaan, pengabstrakan, dan mentransformasi data kasar yang muncul dari catatan tertulis di lapangan. Proses reduksi data ini dimaksudkan lebih menggolongkan, mengarahkan, membuang bagian data yang tidak diperlukan, dan mengelola datanya. Kegiatan reduksi data merupakan hal terpenting bagi peneliti karena terdapat proses memilah dan memilih data untuk memperoleh data yang lebih tajam dan jelas.

Pada tahap reduksi data, peneliti melakukan pengamatan terhadap setiap solusi subjek dalam menyelesaikan masalah barisan bilangan yang diberikan. Pengamatan ditujukan pada langkah-langkah solusi dan tindakan subjek dalam mengkonstruksi konsep melalui pola-pola bilangan. Selanjutnya, tahap penyajian data. ada tahap ini, peneliti menyajikan data melalui klasifikasi subjek dalam mengonstruksi abstraksi reflektif dari banyaknya unsur-unsur abstraksi reflektif yang subjek lakukan. Terakhir, pada tahap 


\section{Histogram: Jurnal Pendidikan Matematika, 4 (2), 2020 - 413 \\ Surya Sari Faradiba' ${ }^{1 *}$, Anies Fuady ${ }^{2)}$, Desy Nofita Sari3)}

penarikan kesimpulan dimaknai sebagai penarikan data yang telah diringkas. Peneliti secara subjektif melakukan pemahaman dan interpretasi terhadap hasil penelitian ini. Beberapa hal terkait penarikan kesimpulan ini adalah melakukan pencatatan pola-pola yang sama dan pencarian kasus-kasus negatif.

Adapun masalah matematika yang digunakan dalam penelitian ini adalah masalah barisan bilangan. Dalam hal ini, di awal telah ditentukan barisan bilangan $1,2,3, \ldots, \ldots$, ... Selanjutnya, subjek diminata untuk menentukan tiga bilangan berikutnya pada barisan bilangan tersebut. Kemudian, subjek diminta untuk menentukan rumus umumnya jika barisan tersebut dilanjutkan hingga suku ke- $n$.

\section{HASIL DAN PEMBAHASAN}

\section{A. Hasil Penelitian}

1. Tahap Interiorisasi

Pada langkah awal, subjek menyelesaikan masalah pertama dengan menuliskan 1, $2,3 \ldots, \ldots, \ldots$. Setelah terdiam beberapa saat, subjek menggambarkan garis lengkung di bawah bilangan-bilangan tersebut untuk menghubungkan bilangan pertama dengan bilangan kedua, bilangan kedua dengan bilangan ketiga, dan seterusnya. Setelah itu, subjek menuliskan di bawah garis lengkung yang telah dibuatnya, selisih antara bilangan pertama dengan bilangan kedua, bilangan kedua dan bilangan ketiga, begitu seterusnya. Diantara bilangan pertama dan bilangan kedua, subjek menuliskan +1 di bawah bilangannya. Sementara itu, diantara bilangan kedua dan bilangan ketiga, subjek menuliskan +2 di bawah garis lengkungnya. Selanjutnya, subjek menggunakan pola ini untuk melengkapi jumlah selisih pada barisan bilangan. Adapun pola yang dimaksudkan adalah $+1,+2, \ldots, \ldots$ yang kemudian digeneralisir menjadi $+1,+2,+1,+1,+2$. Berdasarkan pola tersebut, maka barisan bilangan yang dihasilkan oleh subjek adalah 1, 2, 4, 5, 6, 8. Hasil pekerjaan subjek dapat dilihat pada Gambar 1.

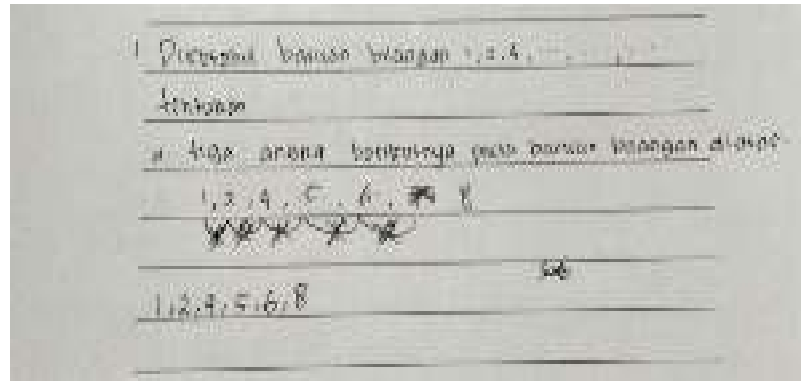

Gambar 1. Solusi Subjek dalam Menyelesaikan Masalah Pertama 


\section{Histogram: Jurnal Pendidikan Matematika, 4 (2), 2020 - 414 \\ Surya Sari Faradiba' ${ }^{1 *}$, Anies Fuady ${ }^{2)}$, Desy Nofita Sari3)}

Untuk lebih memahami gambaran terkait proses penyelesaian masalah yang dilakukan oleh subjek pada masalah pertama, peneliti memberikan pertanyaan berdasarkan hasil pekerjaan subjek setelah proses pengerjaan berlangsung. Berikut ini memuat cuplikan wawancara peneliti $(\mathrm{P})$ dengan subjek $(\mathrm{S})$ terkait proses memahami masalah beserta penjelasannya.

$P$ : "Mengapa jawaban tiga angka berikutnya yaitu 5, 6, 8 ?"

$S$ : "Karena saya ikut yang depan, 1 dan 2 adalah bilangan urut kemudian langsung loncat ke 4. Jadi selanjutnya 5 dan 6 juga bilangan urut dan langsung loncat ke 8."

$P$ : "Mengapa memilih bilangan 5 setelah bilangan 4 ?"

$S$ : "Karena bilangan urutan setelah 4 adalah $5 "$

Cuplikan wawancara di atas, dapat diketahui bahwa subjek sedang melakukan tahap interiorisasi. Hal ini sejalan dengan pendapat Dubinsky (2002), yang menyatakan bahwa interiorisasi merupakan tindakan mengonstruksi proses-proses internal dalam rangka memahami fenomena yang dirasakan.

2. Tahap Koordinasi

Pada langkah selanjutnya, subjek menyelesaikan masalah kedua. Pada tahap ini, subjek diminta untuk menentukan rumus suku ke- $n$ jika barisan bilangan tersebut dilanjutkan hingga suku ke- $n$. Subjek memulai dengan membentuk barisan bilangan dengan selisih yang berpola sama seperti yang telah diselesaikan pada masalah pertama. Sehingga menjadi barisan bilangan yang dapat dilihat pada Gambar 2.

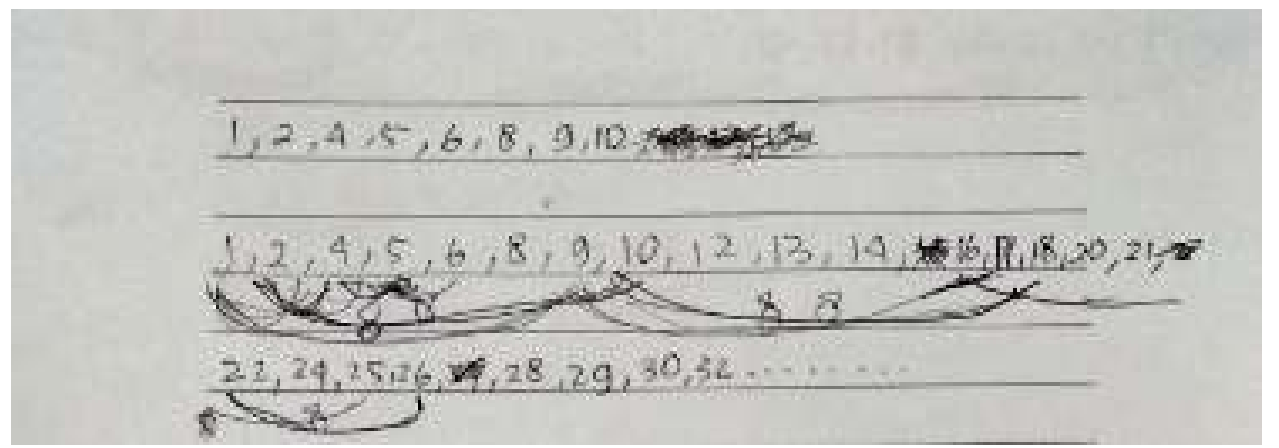

Gambar 2. Hasil Pekerjaan Subjek dalam Menyelesaikan Masalah 2

Subjek membentuk barisan bilangan berlanjut seperti pada Gambar 2 dengan tujuan agar subjek lebih mudah untuk menemukan barisan bilangan baru yang memiliki 


\section{Histogram: Jurnal Pendidikan Matematika, 4 (2), 2020 - 415 \\ Surya Sari Faradiba1)* Anies Fuady ${ }^{2)}$, Desy Nofita Sari3)}

selisih yang sama. Hal ini didukung dengan hasil wawancara oleh peneliti dan subjek sebagai berikut:

$S \quad: \quad$ "Mbak, boleh ya barisan bilangannya sampai banyak?"

$P \quad:$ "Boleh, tetapi mengapa barisan bilangannya mau dilanjutkan sampai banyak?"

$S \quad$ : "Soalnya saya mau mencari bedanya, supaya lebih mudah menurut saya."

Temuan ini sesuai dengan pendapat Dubinsky (2002) yang menyatakan bahwa koordinasi adalah tindakan mengonstruksi proses baru dari dua atau lebih proses yang lain. Proses baru yang dilakukan subjek adalah menambah barisan bilangan yang awalnya $1,2,4,5,6,8$ menjadi $1,2,4,5,6,8,9,10$.

\section{Tahap Pembalikan}

Pada tahap ini, subjek melakukan tiga hal. Pertama, subjek menyatakan pola bilangan baru dengan simbol baru. Kedua, subjek membentuk pola baru lagi dari pola sebelumnya. Ketiga, subjek mendefinisikan pola bilangan atau konsep baru. Subjek memulai dengan membentuk barisan baru pertama dengan selisih 8 yaitu $1,9,17,25, \ldots$. Subjek memulai dengan mengambil dari suku bilangan yang pertama. Kemudian berdasarkan konsep barisan aritmatika, subjek menuliskan rumusan umum untuk barisan baru tersebut yaitu $U_{n}=a+(x-1) b$ dan disubstitusi sesuai dengan barisan baru yang telah dibuat dengan $a$ adalah suku pertama bilangan pada barisan baru dan $b$ adalah selisih pada barisan baru menjadi $U_{n}=8 x-7$. Jadi, rumus suku ke- $n$ pertama yang telah dirumuskan oleh subjek yaitu $U_{n}=8 x-7$. Hal ini sesuai dengan pendapat Dubinsky (2002) yang menyatakan bahwa pembalikan disini adalah pembalikan proses dalam mengonstruk konsep baru secara internal.

\section{Tahap Koordinasi}

Selanjutnya, subjek mengulang langkah yang telah dilakukan pada tahap pembalikan di tahap ini. Subjek membentuk barisan baru kedua dan mengambil dari suku bilangan yang kedua pula dengan selisih 8 juga yaitu 2, 10, 18, 26, ... . Kemudian, subjek menentukan rumus suku ke- $n$ dengan barisan baru yang kedua tersebut sesuai dengan rumus umum barisan bilangan yaitu menjadi $U_{n}=8 x-6$. Jadi rumus suku ke- $n$ kedua adalah $U_{n}=8 x-6$. 


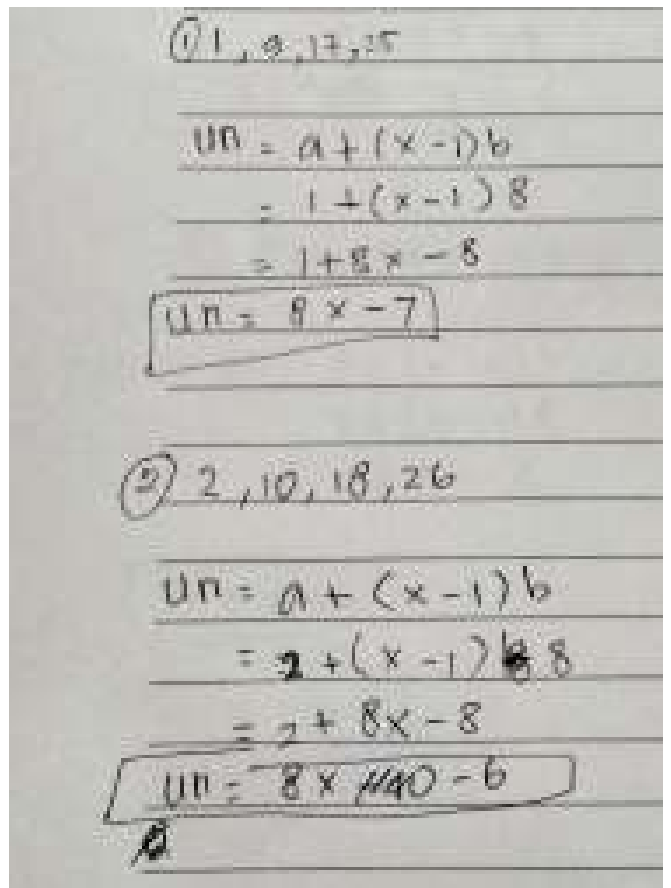

Gambar 3. Pengkonstruksian barisan bilangan baru pertama dan kedua oleh Subjek.

Untuk lebih memahami gambaran langkah penyelesaian, peneliti melakukan wawancara mengenai proses penyelesaian oleh subjek. Berikut ini wawancara peneliti dengan subjek terkait tindakan mengonstruk proses baru adanya barisan bilangan dengan selisih yang sama.

\section{$P \quad: \quad$ "Mengapa setelah bilangan 1 langsung bilangan 9?"}

$S \quad$ : "Karena saya cari yang selisihnya sama mbak, dari 1 ke 9 selisihnya 8, dari 9 ke 17 selisihnya 8,17 ke 25 selisihnya $8 . "$

Jadi, subjek menyusun barisan bilangan baru dengan menentukan selisihnya antara suku bilangan yang memiliki selisih sama. Kemudian untuk langkah selanjutnya, subjek mengonstruk barisan baru yang ketiga dengan mengambil dari suku bilangan barisan ketiga dan barisan baru keempat dengan mengambil dari suku bilangan barisan keempat dengan selisih yang sama. Untuk barisan baru ketiga, subjek menentukan barisan bilangan baru yang diambil dari suku bilangan ketiga yaitu menjadi $4,8,12,16,20,24,28, \ldots$ dengan selisih 4 sehingga rumus suku ke- $n$ nya yaitu $U_{n}=4 x$. Dan untuk barisan baru keempat yaitu $5,13,21,29, \ldots$ dengan selisih 8 sehingga rumus suku ke- $n$ nya $U_{n}=8 x-3$. Dapat dilihat pada Gambar 4 sebagaimana penyelesaian subjek terkait pengkonstruksian barisan bilangan baru. 
Histogram: Jurnal Pendidikan Matematika, 4 (2), 2020 - 417

Surya Sari Faradiba' ${ }^{1 *}$, Anies Fuady ${ }^{2)}$, Desy Nofita Sari3)

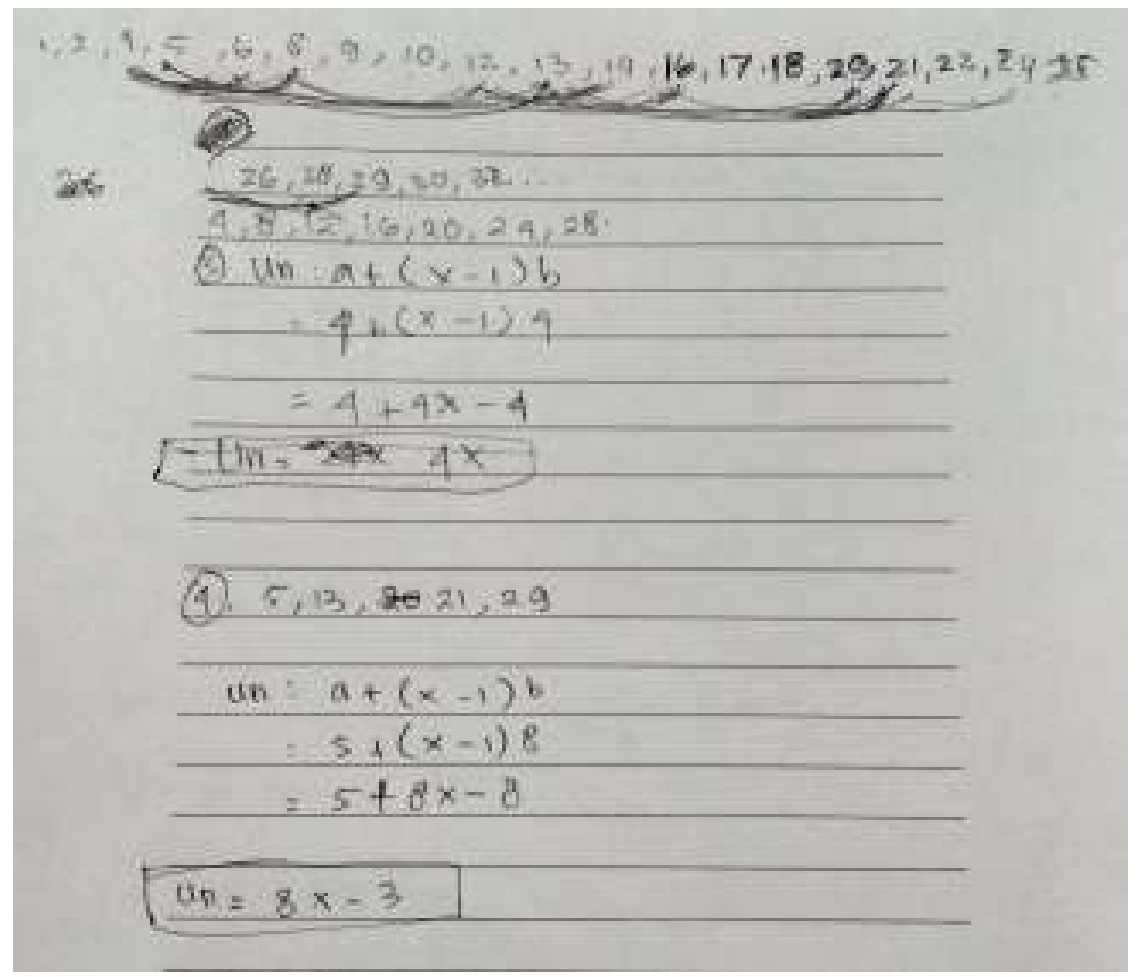

Gambar 4. Pengkonstruksian Barisan Bilangan Baru

Selanjutnya subjek menentukan rumus suku ke- $n$ untuk barisan bilangan baru yang kelima. Menurut subjek, dengan menemukan barisan kelima ini sekiranya cukup untuk menentukan rumus suku ke- $n$. Barisan baru kelima tersebut yaitu $6,14,22,30, \ldots$ sehingga rumus suku ke- $n$ nya yaitu $U_{n}=8 x-2$ dengan selisih 8 . Hal ini sesuai dengan pendapat Dubinsky (2002) yang menyatakan bahwa enkapsulasi merupakan tindakan mengonstruk objek mental dari proses mental. Objek mental yang bersifat statis dan proses mental yang bersifat dinamis. 
Histogram: Jurnal Pendidikan Matematika, 4 (2), 2020 - 418

Surya Sari Faradiba'1), Anies Fuady²), Desy Nofita Sari3)

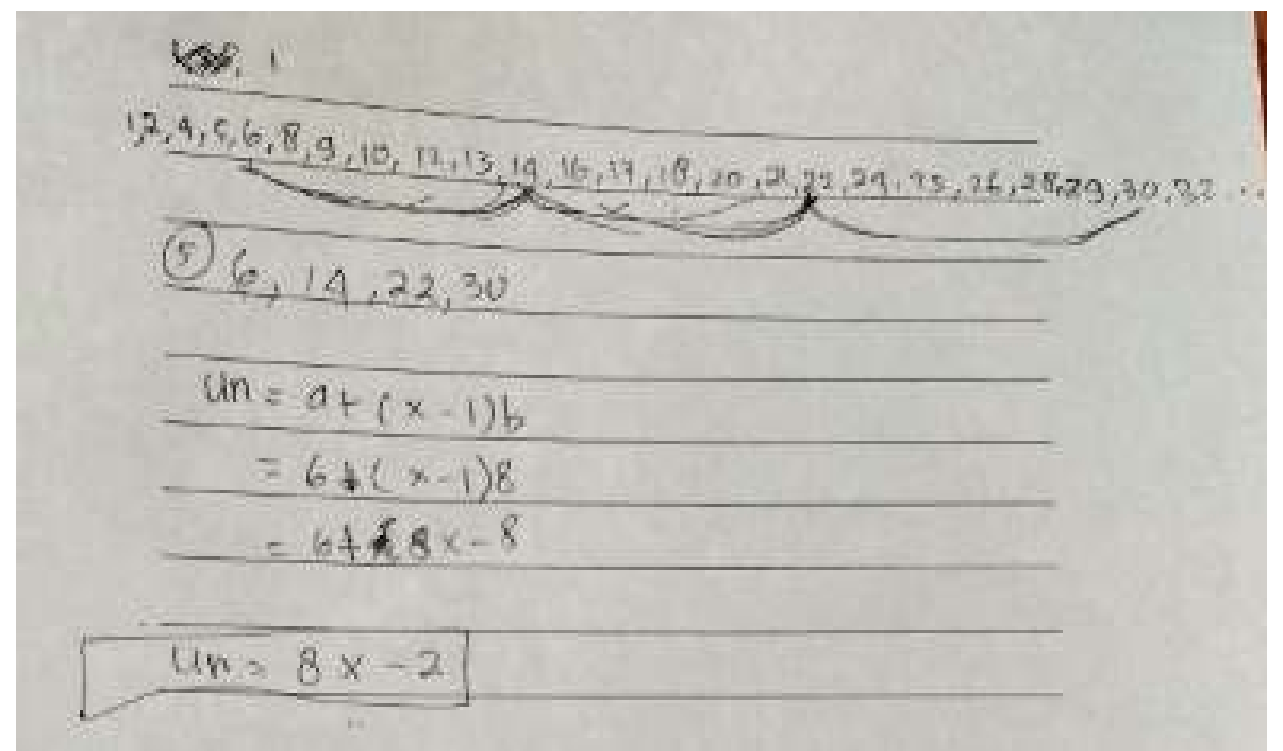

Gambar 5. Pengkonstruksian barisan bilangan baru oleh subjek

\section{Tahap Enkapsulasi}

Dari barisan bilangan yang telah disusun oleh subjek, terdapat bilangan 6 pada suku barisan kelima yang dapat dibentuk barisan bilangan baru dengan selisih kelipatan 6 yaitu $6,12,18,24, \ldots$. Tetapi menurut subjek, untuk suku bilangan 18 tersebut sudah termuat dalam barisan bilangan baru kedua. Jadi, subjek mencari suku bilangan yang lain. Termuat dalam cuplikan wawancara antara peneliti dengan subjek mengenai proses penyelesaian tersebut.

$P$ : "Mengapa tidak mengambil suku barisan 6 kemudian dibentuk barisan bilangan dengan selisih kelipatan 6 ?"

$S$ : "Tidak mbak, karena 18 sudah saya muat pada barisan bilangan baru yang kedua."

$P:$ : Jadi, supaya tidak sama ya?"

$S:$ : Iya mbak."

\section{Tahap Generalisasi}

Penyelesaian selanjutnya, peneliti meminta subjek untuk menuliskan semua rumus suku ke- $n$ yang telah ditentukan. Kemudian subjek menyatakan semua rumusan umum tersebut dengan membuat ringkasan umum sebagaimana dapat dilihat pada Gambar 6 . 


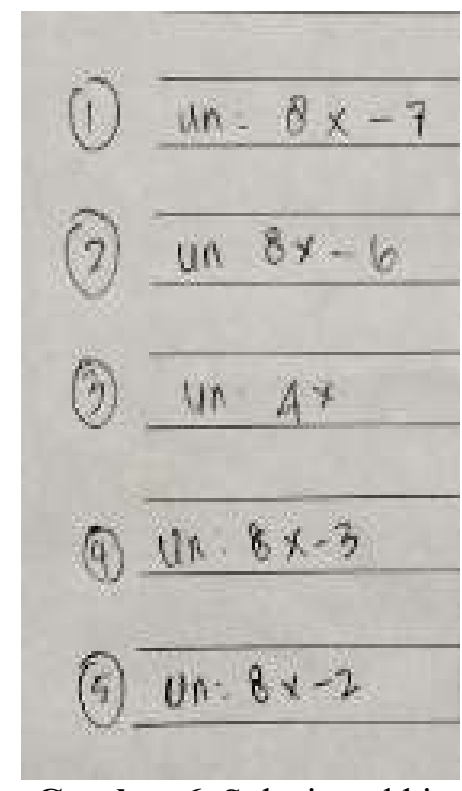

Gambar 6. Solusi terakhir

Bentuk umum yang merupakan rumus umum suku ke- $n$ dari barisan bilangan 1, 2, $4,5,6,8,9,10,12,13,14,16,17,18,20,21,22,24,25,26,28,29,30,32, \ldots$ adalah hasil penyelesaian oleh subjek pada gambar 4.6 diatas yang diselesaikan dari tahapan-tahapan sebelumnya melalui pengulangan-pengulangan cara yang sama. Hal ini didukung dengan hasil wawancara yaitu wawancara terstruktur yang dilakukan peneliti sesaat setelah subjek menyelesaikan masalahnya, adapun cuplikan wawancara adalah sebagai berikut:

$P \quad:$ :apakah kamu paham dengan masalah ini ?"

$S \quad:$ "iya sedikit paham sedikit tidak"

$P \quad:$ "tidak pahamnya dimana?"

$S$ : "tidak paham di selisihnya (beda) kalau di sekolah sama, kalau disini selisihnya beda-beda. "

$P \quad:$ " $h m$, sebelum kamu menuliskan penyelesaian di lembar solusi tadi apa yang ada pada pikiran kamu?"

$S \quad:$ "yaa, coba-coba."

$P \quad:$ :apakah kamu yakin dengan jawabanmu?"

$S \quad:$ "yakin."

$P \quad: \quad$ "jadi kesulitannya dari masalah ini yang pertama karena kalau di sekolah selisihnya itu sama, kalau disini selisihnya tidak sama. Misalnya saya minta kamu menyelesaikannya dengan strategi yang lain bisa atau tidak?"

$S \quad$ : "bisa saja tetapi memerlukan waktu lagi."

$P \quad: \quad " k e m u d i a n$ dapatkah kamu menceritakan bagaimana proses mengerjakan masalah ini ?"

$S$ : "ya yang pertama saya menentukan tiga angka berikutnya. Saya menentukan itu dari tiga angka yang di depan. Jadi saya ikuti pola tersebut karena 1 dan 2 adalah bilangan urutan kemudian langsung loncat ke 4. Jadi, selanjutnya 5 dan 6 juga bilangan urutan kemudian langsung loncat 


\section{Histogram: Jurnal Pendidikan Matematika, 4 (2), 2020 - 420 \\ Surya Sari Faradiba' ${ }^{1 *}$, Anies Fuady ${ }^{2)}$, Desy Nofita Sari3)}

ke 8. Kemudian saya buat barisan bilangan sampai banyak. Menurut saya, supaya lebih mudah untuk menentukan selisihnya (beda) kemudian bisa ditentukan rumus suku ke-n nya."

\section{B. Pembahasan}

Goedecke (2013) menyimpulkan bahwa abstraksi merupakan generalisation and modelling. Dinyatakannya pula bahwa abstraksi dapat digunakan untuk memudahkan atau menyederhanakan suatu pekerjaan, menstrukturkan pikiran seseorang, mengklarifikasi antar koneksi, membuka area baru, menyelesaikan masalah, dan membuat ide baru. Sedangkan Warsito (2019) menegaskan bahwa abstraksi adalah sebuah aktivitas yang merupakan proses mental dalam membentuk suatu konsep matematika yang melibatkan hubungan-hubungan antar struktur atau objek-objek matematis, seperti yang telah dilakukan subjek dalam penelitian ini.

Sesuai dengan pendapat Goodson-Espy (dalam Panjaitan, 2017: 1), menjelaskan abstraksi reflektif mengacu pada kemampuan subjek untuk memproyeksikan ke tingkat yang baru dan menata ulang struktur yang dibuat dari kegiatan dan interpretasi subjek itu sendiri. Dilihat dari penyelesaiannya, subjek telah memaparkan jawaban untuk melanjutkan barisan berulang dengan pola selisih yang sama sesuai dari tiga bilangan di barisan awal menggunakan strategi yang baru.

Kemampuan abstraksi siswa dalam menyelesaikan masalah juga sangat diperlukan, sejalan dengan pendapat Goodson-Espy (dalam Fuady, 2018: 465) menyatakan hasil abstraksi mental seseorang adalah skema yang digunakan untuk memahami berbagai hal, mencari solusi, ataupun memecahkan masalah. Dalam kegiatan pemecahan masalah dalam suatu situasi, siswa sering menghubungkan aktivitas ke situasi pemecahan masalah yang berikutnya. Sehingga siswa akan lebih kreatif dalam menghadapi dan menyelesaikan masalah yang berikutnya. Dilihat dari penyelesaian subjek yang berikutnya, subjek membentuk barisan bilangan baru untuk menentukan rumus umum jika barisan bilangan dilanjutkan hingga suku ke- $n$. Pada langkah tersebut, subjek mampu menata ulang struktur barisan dan mampu menentukan rumus umumnya tetapi hasil dari rumus tersebut apabila disubstituskan tidak dapat menghasilkan nilai yang sama dengan barisan bilangan awal yang utuh. Di sini subjek tidak memperhatikan hubungan aktivitas ke situasi pemecahan masalah yang berikutnya. Hal itulah yang menjadi abstraksi reflektif subjek mengalami kesalahan meskipun aktivitas abstraksi nya dilakukannya dengan lengkap dan baik. 


\section{Histogram: Jurnal Pendidikan Matematika, 4 (2), 2020 - 421 \\ Surya Sari Faradiba1)* Anies Fuady ${ }^{2)}$, Desy Nofita Sari3)}

\section{KESIMPULAN DAN SARAN \\ A. Kesimpulan}

Dalam penelitian ini subjek melakukan semua tahap abstraksi reflektif mulai dari interiorisasi, koordinasi, pembalikan, enkapsulasi, dan generalisasi, namun solusi akhirnya salah. Fenomena ini dikatakan sebagai pseudo abstraksi reflektif atau abstraksi reflektif semu. kondisi ini hanya berlaku pada subjek yang ada dalam penelitian ini. Dengan kata lain, kesimpulan tidak bisa digeneralisasi karena jumlah sampel yang tidak representatif.

\section{B. Saran}

Perlu diuji kekonsistenan hasil penelitian ini dengan melibatkan lebih banyak subjek dengan masalah matematika yang bervariasi. Selain itu patut dipertimbangkan untuk meneliti subyek yang meliki prestasi akademik yang beragam, untuk menguji kekonsistenan dari hasil penelitian ini. Adapun masalah matematika yang digunakan dalam peneliti perlu juga ditambahkan supaya lebih bervariasi, baik variasi pada model soal maupun variasi pada materi soal

\section{DAFTAR PUSTAKA}

Afgani, M, W., Suryadi, D., Dahlan, J, A. (2017). Analysis of Undergraduate Students' Mathematical Understanding Ability of the Limit of Function Based on APOS Theory Perspective. IOP: Journal of Physics: Conference Series. 895-012056, 1-7. Dubinsky, Ed. (2002). Reflective Abstraction in Advanced Mathematical Thinking, in Advanced Mathematical Thinking, Tall, David (ed), pp.95-123, Kluwer Academic Publisher

Fuady, Anies, dkk. (2018). Abstraksi Reflektif Siswa Dalam Memecahkan Masalah Matematika Berdasarkan Gaya Kognitif. Seminar Nasional Pendidikan Matematika Ahmad Dahlan 2018. ISSN: 2407-7496. Hal: 464-471.

Goedecke, J. (2013). Abstraction in Mathematics. Queen's College.

Maharaj, A. (2014). An APOS Analysis of Natural Science Students' Understanding of Integration. REDIMAT. Vol: 3 (1): 54-73.

Miles, B. Mathew dan Michael Huberman. (1992). Analisis Data Kualitatif Buku Sumber Tentang Metode-metode Baru. Jakarta: UIP.

Nardi, E. (2017). From Advanced Mathematical Thinking to University Mathematics Education: A Story of Emancipation and Enrichment. CERME 10, 8-31.

Nisa, LC., Waluya, SB., Kartono., Mariani, S. (2020). Implementation of APOS Theory to Encourage Reflective Abstraction on Riemann Sum. Journal of Physics: Conference Series. 1567-032014, 1-5.

Panasuk, R.M. (2011). Taxnomy for Assesing Conceptual Understanding in Algebra Using Multiple Representation. College Student Journal. Volume 45 (2): 219-232.

Panjaitan, B. 2018. The Reflective Abstraction Profile of Junior High School Student In Solving Mathematical Problems Based on Cognitive Style of Field Independent And Field Dependent. Journal of Physics: Conference Series. 
Histogram: Jurnal Pendidikan Matematika, 4 (2), 2020 - 422

Surya Sari Faradiba ${ }^{1)^{*}}$, Anies Fuady²), Desy Nofita Sari3)

Simon, Martin A., Tzur, Ron., Heinz, Karen., \& Kinzel, Margaret. (2004). Explicating A Mechanism for Conceptual Learning: Elaborating The Construct of Reflective Abstraction. Journal for Research in Mathematics Education 35 (5), 305-329.

Thomas, M.O.J., de Freitas, Druck, I., Huillet, D., Ju, Mi-Kyung., Nardi, E., Rasmussen, C., Xie, J. (Ed). (2015). The Proceedings of the 12th International Congress on Mathematical Education. Seoul, Korea: Springer Open.

Warsito. Saleh, Hairul. (2019). Analisis Abstraksi Matematis Melalui Tematisasi Progresif Dengan Pembelajaran Matematika Realistik Pada Pembelajaran Geometri. Seminar Nasional Penelitian Pendidikan Matematika, 198-206. 